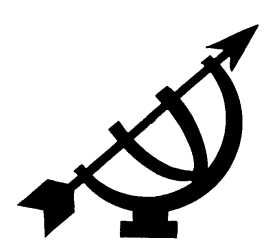

\title{
In pursuit of a foundational accountancy philosophy
}

\author{
P. Buys \\ School of Accounting Sciences \\ Potchefstroom Campus \\ North-West University \\ POTCHEFSTROOM \\ E-mail: Pieter.Buys@nwu.ac.za
}

\begin{abstract}
In pursuit of a foundational accountancy philosophy

Recent accounting history is characterised by many developments, including several high-profile corporate failures, such as Enron, Parmalat and even Saambou, as well as major developments in financial reporting standards, such as the broadbased acceptance of international financial reporting standards and the convergence efforts between the UK-based International Accounting Standards Board and the US-based Financial Accounting Standards Board. As a result, long-accepted accounting assumptions are being challenged in favour of new principles and practices. Furthermore, in academic circles the scientific foundation of accounting is being questioned. At many universities, limited education is taking place in the underlying theory and philosophy of accounting in favour of teaching prospective accountants how to pass difficult professional exams.
\end{abstract}

Seen against this backdrop, a reconsideration of the objectives and purpose of accountancy may be overdue. This article attempts to illuminate the intrinsic assumptions and objectives of accountancy, seen in the light of modern-day accounting issues and developments.

\section{Opsomming}

Die strewe na 'n grondliggende filosofie vir rekenmeesterskap

Onlangse rekeningkunde geskiedenis word gekenmerk deur baie ontwikkelings, insluitend verskeie hoë-profiel korporatiewe mislukkings, soos Enron, Parmalat en selfs Saambou, asook belangrike ontwikkelings in finansiële verslagdoening, soos die 
wydverspreide aanvaarding van internasionale finansiële verslagdoeningstandaarde en die samesmeltingspogings tussen die VK-gebaseerde Internasionale Rekeningkundige Standaarde Raad en die VSA-gebaseerde Finansiële Rekeningkundige Standaarde Raad. As gevolg hiervan, word aanvaarde rekeningkundige aannames lank reeds bevraagteken ten gunste van nuwe beginsels en praktyke. Verder word die wetenskaplike grondslae van rekeningkunde in akademiese kringe bevraagteken. By baie universiteite vind beperkte opvoeding in die grondliggende teorie en filosofie van rekeningkunde plaas, ten gunste van pogings om voornemende rekenmeesters te leer hoe om moeilike professionele eksamens te slaag.

Gesien teen hierdie agtergrond, is die heroorweging van die doelwitte en doelstellings van rekeningkunde waarskynlik alreeds nodig. Hierdie artikel poog om lig te werp op die intrinsieke aannames en doelwitte van rekenmeesterskap, in die lig van moderne rekeningkundige probleme en ontwikkelings.

\section{Background}

... my great ambition is to count all this ... and possibly sort it into piles (Gardner, 1989:73).

Some may consider the dragon's ambition (in the classical Beowulf poem) as a key objective of accountancy, and as a way of avoiding any philosophical dilemmas facing a person engaged in financial reporting. Using the term philosophy in connection with accounting may be met with some scepticism. However, when considering the many articles in accountancy publications, such as in Cluskey et al. (2007), Sundem (2007), Mattessich (2003), and Husband (1954), there seems to be at least a search for an accounting philosophy. Philosophy can be defined as the study of the most general and abstract features of the world and the categories with which we think (Blackburn, 1994:286), or as the study of the principles underlying, or fundamental nature, of a field of knowledge (Webster's Dictionary and Thesaurus, 2006:277, Oxford English Dictionary, 2004:413). This means that applying a philosophical approach to accountancy should be just as possible as to any other area of practical learning. However, in the past there have been some practitioners who denied the usefulness of accounting philosophy, arguing that historical traditions and practices provide the required support (Husband, 1954:4).

Accounting seems to be tied up within thousands of rules, regulations, interpretations and opinions, all based on the requirements of practice. Historically, accounting standards have also been seen 
as such a specialist area, that many large accounting firms had their own in-house functions focusing primarily on the interpretation of these standards (Zeff, 1986:133-138). Two of the primary global accounting standard-setting authorities, the Financial Accounting Standards Board (FASB) and the International Accounting Standards Board (IASB), have different approaches to define accepted accounting practices. The FASB's approach consists of four levels:

- Level A includes FASB statements and interpretations, SEC rules and interpretive releases, accounting principles, board opinions and bulletins;

- Level B includes FASB technical bulletins and AICPA industry audit guidelines;

- Level C includes AcSEC practice bulletins; and

- Level D includes AICPA accounting interpretations, FASB implementation guides and other prevalent accounting practices (Epstein et al., 2005:8; Schroeder et al., 2005:17). The IASB's approach consists of a two-volume, 2522-page text, containing eight International Financial Reporting Standards (IFRSs) and sixteen International Accounting Standards (IASs) (IFRS, 2006).

The IASB's approach consists of a two-volume, 2522-page text, containing eight international financial reporting standards (IFRSs) and sixteen international accounting standards (IASs) (IFRS, 2006).

Graham and Meredith (1937:vii) stated 70 years ago that financial statements and their interpretations are essential for every businessman that comes into contact with a company and its securities. This is still true, but seen in the light of the recent high-profile corporate failures, one starts to wonder whether the true purpose and objective of accountancy have not become muddled in the overload of rules and regulations.

\section{Problem statement}

Seen within the context of the recent accountancy controversies on income measurement, accounting information disclosure and corporate social responsibility issues, it is not far-fetched to state that a philosophical reconsideration of the basic purposes of accountancy may be overdue. Considering the foundational objectives of accountancy, the problem statement can therefore be defined as follows: 
Is it possible to define a legitimate accountancy philosophy that also embraces key ethical principles, such as accountability, integrity and reliability?

\section{Method}

It would be difficult to present a stronger challenge or better argument for the urgent need of an underlying accountancy philosophy, than that which characterises the profession's current status. In addressing this need, consideration has to be given to modernday philosophical issues facing accountancy, and modern-day practical issues facing accountancy.

This article attempts to evaluate accounting's pre-suppositions. In order to do so, the research method comprised a transcendental discussion and analysis aiming to individuate the deeper foundations of accountancy's system of thought. This is supported by a review of the historic and current developments in accountancy and accounting theory.

\section{Philosophical issues facing accountancy}

In order to develop a legitimate, foundational accountancy philosophy, one needs to consider the objectives of accountancy, the foundational perspectives on accountancy, as well as the ethical issues in accountancy.

\subsection{Objectives of accountancy}

Financial reporting aims to provide information about an entity's financial performance (Sundem, 2007:287; Damant, 2006:30; IFRS, 2006:26), of which the entity's accounting system provides a recorded history. The accountants (or historians) need to decide what business information (or historic events) to include and to exclude (Sundem, 2007:287; Perry \& Nölke, 2006:559-560). The role of the accounting standard setters is therefore to decide which details of this history are important enough to warrant disclosure and what the extent of such disclosure should be. However, there are other stakeholders that should also partake in the formation of these rules, including industry, the accounting profession, labour unions and academia (Epstein et al., 2005:5-7; Busse von Colbe, 1996: 414).

A consequence of the growing diversity of companies and the closeknit relationships of many sectors within the greater economy is that accountancy is exposed to great responsibility and risk, reaching 
beyond the immediate task of the profession. This places significant pressure on the standard-setting authorities, which impacts on more than just the accounting methods utilised. It may also open up the option of choice of accounting method used, which in turn may influence decision-making. As a business language to communicate financial performance, accounting has many interested stakeholders that have different informational requirements. To further complicate matters, many of these stakeholders have some influence on how and what accounting information should be disclosed. Seen in this context, it is not surprising that so many complex accounting rules and ethical dilemmas are at the order of the day.

\subsection{Foundational perspectives on accountancy}

As an academic discipline, accountancy is in a difficult position because the requirements of practice have a major impact on accounting education. However, there are fundamental assumptions in accounting, and its place in the greater socio-economical environment, that have to be considered. The history of accountancy is characterised by various two-sided perspectives, namely art versus science, and true income versus decision usefulness.

\subsubsection{The "art versus science" perspective}

When considering accountancy as a business discipline, there are two heterogeneous approaches, namely the scientific-based and artbased approaches (Fellingham, 2007:160; Riahi-Belkaoui, 2000:34; Wolk, et al., 1992:36). Art may be defined as a human creativity or skill, acquired through study and practice (Webster's Dictionary and Thesaurus, 2006:21; Oxford English Dictionary, 2004:26), while the philosophy of art also dealt, among others, with the nature of human creativity (Cambridge Dictionary of Philosophy, 2005:12). Science could be defined as the knowledge ascertained through observation and experimentation, critically tested, systematised and brought under general principles (Webster's Dictionary and Thesaurus, 2006: 336; Oxford English Dictionary, 2004:496), while the philosophy of science, according to the Cambridge Dictionary of Philosophy (2005:700) and The Oxford Dictionary of Philosophy (Blackburn, 1994:343), is the investigation of questions that arise from reflection upon the science and scientific practice. Those who promote the art aspects of accountancy, suggest that specialist functional skills are required to be a good accountant, and that it should be taught in a legalistic approach (Riahi-Belkaoui, 2000:34). In contrast, the advocates of a scientific approach, such as Demski (2007:153-156) and Fellingham (2007:159-163), suggest that students be provided a 
conceptual insight into accounting in order to provoke critical thought towards its dynamics.

Although many accounting scholars have tried to make the discipline more scientific, Mattessich (2003:126) says this would not be achievable with the parochialism that characterises twentieth century accounting. Focusing on its functional aspects, accounting can be defined as the generic term for the activities carried out by accountants (CIMA Dictionary of Finance and Accounting, 2003:5), as a broad term that encompasses the preparation, analysis and audit of financial information (O'Regan, 2004:5), or as the art or practice of an accountant (Webster's Dictionary and Thesaurus, 2006:5).

As a discipline, accounting is concerned with the business events of business entities, which in turn has consequences for the stakeholders' social relationships. Accounting is very much concerned with the human element and produces business information, aimed at helping people to engage in social activities with social implications. Therefore, when considering whether accounting is an art or a science, the answer is clearly not a straightforward yes or no. In reality, many of its functional aspects can be considered an art form, and should be taught in an artisan approach. Likewise, there are foundational aspects that justify its science classification, and should be taught in a scientific approach. However, because of the integrated nature of accounting in society, and its impact thereon, one cannot deny accounting its rightful place in the social sciences.

\subsubsection{The "true income versus decision usefulness" perspective}

Perhaps contributing further to the legitimacy and ethical concerns facing accountants, are the multiple purposes for which accounting information is prepared and used. During the 1970s, accounting scholars entered into a debate that conceptualised accounting theory as a struggle between the proponents of true income and the advocates of decision-useful information (Cluskey et al., 2007:26). The question under discussion was whether accounting should provide for financial information that reflects the true income, albeit with limited usefulness, or financial information that supports decisionmaking, albeit not necessarily being objective or verifiable. It is possible to define the following two alternative views on accounting information: 


\section{- Value school of thought}

This approach is based on the measurement of wealth and its effectiveness is judged based on how well it approximates the value of the wealth items (Sundem, 2007:288; Schroeder et al., 2005:42). The question remains as to what true value means, and how to measure it. However, the assumption is that there is a value and the accounting efforts are attempting to measure it.

\section{- Information content school of thought}

This approach focuses on measuring and disclosing business events. Its effectiveness is judged based on how well such disclosure and communication are concluded (Sundem, 2007:288; Schroeder et al., 2005:42). Even though the disclosure of business information attempts to reduce uncertainty regarding the entity, the multidimensional nature of business entities makes the concept of effective information communication difficult to evaluate.

Therefore, the many stakeholders in, and users of, accounting information, as well as the differences between using such accounting information either as purely a historical measurement tool, or as a pro-active management support tool, are all major influencing factors on how the individual accountant would approach accountancy.

\subsection{Ethical issues in accountancy}

As mentioned, accounting aims to translate and report business performance, in support of business decisions, into monetary terms. As such, accounting is a crucial component of doing business. The ethical issues of the business environment is therefore very much part of accountancy's ethical dilemmas. It could be a fair assumption to state that someone well versed in the philosophy of ethics may best serve ethical business issues. However, philosophers and business professionals approach ethical issues in very different ways (Nash, 2003:22):

- Academics tend to reflect on the intangible, savour the paradoxical and embrace the peculiar; while

- the reality of the business environment is constantly measuring claims on available resources against the marketplace.

According to Lotriet (2007:424), there is no foundational ethic in the modern-day technology-driven network economy. Therefore, if the financial statements are to be of any value to the stakeholders, they must have confidence in the fairness of the disclosed information. 
These stakeholders will have more confidence in such information if they know that the preparers thereof are required to meet certain ethical and competency standards. It is therefore not surprising to find that many professional accountancy institutes require their members to adhere to a code of ethics (IMA, 2008; CICA, 2007; ICAEW, 2006; SAICA, 2006; AICPA, 2003). Why then is it that many apparently good accountants are snared in ethical problems?

A commonly held rationalisation is a belief that if an activity is within reasonable ethical or legal limits, it is not really immoral (Gellerman, 2003:51). However, acting ethically only when it is advantageous is not really being ethical at all. Furthermore, good corporate governance does not only necessitate abiding by the laws and respecting human rights. Rossouw (2002:412) states that it also entails the strengthening and development of the societies in which a business operates. According to Andrews (2003:73-75) and Gellerman (2003:49), in business situations where there are no absolute choices, the character of the individual becomes decisive. Although such character may be shaped by the individual's upbringing, i.e. family, church and education, the increased secularisation of society may limit such influences in ensuring a moral society (Andrews, 2003:6970).

Accounting standards and ethical guidelines alone will not ensure ethical behaviour on the part of the individual accountant. The challenge facing ethics in accountancy should therefore be considered from three perspectives. Firstly, the development of moral accountants who have a respect for core human values, the ability to recognise ethical issues and the self-confidence to seek out different viewpoints before deciding what is appropriate in a situation. Secondly, the creation of an environment in which accounting standards and values are central to the business strategy, and finally, the formulation, implementation and monitoring of guidelines and policies that promote ethical accountancy behaviour.

\section{Practical issues facing accountancy}

A second important aspect to consider is the influence of the practical accounting environment, such as issues around measurement and valuation. However, it is important to base such consideration on accountancy development and the accounting conceptual framework. 


\subsection{Accountancy development}

An Italian monk, Luca Pacioli, is often seen as the father of accounting (Cluskey et al., 2007:25). In 1494, he published a mathematical compendium, Summa de arithmetica geometria proportioni et proportionalita, 1 which included a 27-page treatise on bookkeeping, Particularis de computis et scripturis ${ }^{2}$ (Sangster et al., 2008:111; Schroeder et al., 2005:3; Riahi-Belkaoui, 2000:3). Essentially explaining the practice of accountancy at the time, Pacioli also explained why the double-entry bookkeeping approach made sense (Cluskey et al., 2007:25; Schroeder et al., 2005:3). It is thought that during this age, accounting skills were the domain of merchants, who were typically educated in the vernacular schools where abbaco, or the skill to solve practical and business-related problems, was taught (Sangster et al., 2008:117).

In the more recent history of accounting, the discipline has grown from its role as a practical business skill, into a sophisticated business tool. Mattessich (2003:126) states that many professionals are unaware of how many modern accounting ideas were conceived during the nineteenth and early twentieth centuries. A major accounting concern of this era was the development of a theory that could address the corporate abuses of the time. This gave rise to the concepts of capital maintenance and income determination (Schroeder et al., 2005:4-5). During the 1950s and 1960s, accounting was approached as a measurement activity, aiming to provide a truthful description of economic events. The 1960s and 1970s was an era when accounting theorists started to develop innovative analytical approaches (Feltham, 2007:2-7). As far as modern-day accounting theory is concerned, Schroeder et al. (2005:113) and Wolk et al. (1992:32-33) distinguish between normative accounting theory that explains what should be, and positive accounting theory that explains what is.

Accountancy can therefore be seen as a practical skill to be used in a business environment. As such, the application of such skills becomes dependent on the accountant's values, and his perceptions of accounting theory. Several accounting theorists, such as Cluskey et al. (2007), Schroeder et al. (2005) and Riahi-Belkaoui (2000)

1 Collected knowledge of arithmetic, geometry, proportion and proportionality.

2 Details of reckonings and their recordings. 
have defined accounting theory as the framework of accounting principles that guide and inform accounting practitioners and educators.

\subsection{The accounting conceptual framework}

The FASB and the IASB can be considered as representing two sides of the accounting standards spectrum, with the FASB largely following a rules-based approach and the IASB following a principles-based approach (Epstein et al., 2005:12; Schroeder et al., 2005:59). Even though the conceptual framework is intended to provide guidance when developing accounting policies, its goal as a roadmap for the development of accounting standards, has remained elusive and endemic with internal inconsistencies (Demski, 2007:154; Sundem, 2007:286). Consideration is therefore given to the concept of GAAP, and certain key assumptions underlying GAAP.

\subsubsection{The concept of GAAP}

The phrase GAAP is, according to Epstein et al. (2005:1), a significant concept and the technical term that encompasses the conventions, rules and procedures necessary to define acceptable accounting practice at a particular time. GAAP is often taken as the abbreviation of generally accepted accounting principles and is used in countries like Australia (ICAA, 2008), Canada (CICA, 2005), the UK (ICAEW, 2008) and the USA (FASB, 2006). However, in South Africa, GAAP is typically taken as generally accepted accounting practices (Everingham et al., 2007:2; Sowden-Service, 2006:6).

Although the concept of GAAP seems to be based on either principles or practice, there is a difference in interpretation. Principle may be defined as a fundamental truth on which others are founded (Webster's Dictionary and Thesaurus, 2006:295) or a general law used as a basis for a theory (Oxford English Dictionary, 2004:438), whereas practice can be defined as the actual doing or exercising of a profession (Webster's Dictionary and Thesaurus, 2006:290; Oxford English Dictionary, 2004:431). Be that as it may, before a principle or practice becomes GAAP, it should have substantial authoritative support. It may therefore seem as if a practice-based GAAP definition is more reflective of reality. However, Demski (2007:153$156)$ and Fellingham (2007:160-162) regard that a principles-based GAAP approach in accounting theory education is important in order to ensure the academic status of the accountancy discipline. 


\subsubsection{GAAP assumptions under consideration}

Out of necessity, accountancy is practiced in a framework of basic assumptions. An assumption is the act of taking a statement for granted, or as the basis of an argument (Webster's Dictionary and Thesaurus, 2006:23), or assumed a thing to be true (Oxford English Dictionary, 2004:29). To clarify the context of an assumption, The Oxford Dictionary of Philosophy (Blackburn, 1994:27) states that a proposition is treated as an assumption when it is added to a stock of premises of an argument, upon which a conclusion is then conditional. Therefore, in the face of business uncertainty, assumptions are used to facilitate financial measurement and reporting. However, in the reality of the modern-day business environment, the relevance of certain accounting assumptions may be questioned.

\section{- $\quad$ Separate-entity}

This assumption can be considered of primary rank in the accounting framework. It defines its area of interest as the economic unit responsible for the economic activities (Wild, 2008:10; Epstein et al., 2005:65; Wolk et al., 1992:131). However, another way of defining the accounting entity may be in terms of the various stakeholders' interests, i.e. a user-focused as opposed to a unit-focused approach. By focusing on the stakeholder instead of the shareholder, it becomes possible to address stakeholder-interests other than the financial bottom-line.

\section{- Going-concern}

This assumption justifies the valuation of assets on a non-liquidation basis (Wild, 2008:9; Sowden-Service, 2006:18-19; Epstein et al., 2005:377). This postulate may also serve as a way to encourage stakeholders to be future orientated. However, considering the recent accounting scandals (such as Enron in the USA, Parmalat in Italy and Saambou in South Africa) and the implications thereof, this assumption may be presumptuous. In fact, there are accounting theorists who prefer to exclude the going-concern assumption from accounting theory by viewing the entity as if in a continuous state of orderly liquidation (Riahi-Belkaoui, 2000:165).

\section{- Unit of measure}

This assumption acknowledges the necessity of recording the transactions in a consistent manner by choosing the monetary unit as the common denominator (Wild, 2008:9; Riahi-Belkaoui, 2000: 165; Wolk et al., 1992:115). However, this implies two limiting factors of conventional accounting, namely its ability to express infor- 
mation only in terms of monetary units, and its inability to communicate non-monetary information. In addition, under the going-concern assumption, this postulate also holds the common denominator as a stable currency, which is a rare occurrence in the current-day and age.

When considering how accounting is taught, and what is taught, it does indeed seem as if accounting theory is based on a set of generally accepted accounting practices. For accountancy to be based on these assumptions to protect the investment community for example, is one thing, but to offer as a sound accounting theory that which is basically no more than recommended practices, is to intellectually bankrupt the accounting discipline.

\subsection{Accountancy's measurement issues}

Some economic historians consider the double-entry bookkeeping system as vital to the development of capitalism. Riahi-Belkaoui (2000:12-13) summarised its impact on economic expansion as follows:

- It contributed to an economic life attitude where the goal of subsistence was replaced with the goal of profit;

- the spirit of acquiring possessions was aided by the refinement of the economic calculations;

- its systematic approach promotes order and provides for an accuracy check; and

- it permits a separation of ownership and management, and thus also a separation between business and personal assets.

Two of the primary financial statements are the income statement, which reflects the operational performance and results, and the balance sheet, which reflects the financial situation at a particular time (Wild, 2008:17-18; Epstein et al., 2005:64). How the income (and expense) items are measured, and how the assets (and liabilities) are valued, are key factors in the perceived performance of the organisation. The aspects of income determination and value determination are therefore now considered.

\subsubsection{Income determination}

Understanding the relationship between business management and accounting can lead to the recognition of accounting's ultimate goal, namely the provision of the basic answer about an organisation's 
financial performance. It fulfils this central purpose through the measurement of the organisation's efforts and performance (Epstein et al., 2005:64; Wolk et al., 1992:266-267), which is summarised in its profits (or lack thereof). However, what is the meaning of profit or income?

Since investors risk their capital and apply their skills to find ways to render profitable products and services, they should be entitled to all income, except that which is required to meet the obligations of other stakeholders (Schroeder et al., 2005:128-129; Jensen, 2002:236). This dualistic concept, profit and product/service, contributes to the difficulty in defining business income. Profit refers to the owner's interest in the entity's operations, whereas product/service refers to the market's interest in the entity's operations. The combination hereof forms the foundation of the free enterprise system. It could therefore be argued that the theory of business economics is not about money, but to satisfy the market needs - the profit motif is the entrepreneur's incentive to act (Shillam, 2008:23).

By combining the service delivery concept with the business objectives, it becomes possible to answer the question of what accountancy is for, and a well-considered application of this concept may offer a valid foundation on which to base a constructive income philosophy, encompassing three components:

- income is the total compensation received for the delivery of products and services;

- full compensation is only acknowledged when the income enables the organisation to continue its operations as before; and

- the excess of the proceeds over what is required for full compensation, is the available profit.

\subsubsection{Value determination}

Accounting theory is confronted with the phenomenon of relative values (Mattessich, 2003:129-146). Even the obvious cost-value concept can become debatable. When capitalising the price of a purchased object, the simple historical fact is that an amount has been spent for the acquisition of the object. This does not mean that the acquired object is worth that amount. However, asset values are key quantitative anchors upon which capitalism is based, and the way it is valued can be considered a key parameter in socioeconomic relations. 
Whereas the traditional accounting approach uses the cost principle to value business assets, there is a move to introduce fair value accounting (Christensen \& Frimor, 2007:35). Fair value accounting (or FVA) presents such a mind shift in accounting that Perry and Nölke (2006:561) called it the most significant change IFRS has brought to accounting, which presents itself in the FVA and balance sheet approaches.

\section{- $\quad$ Fair value accounting}

FVA can be defined as the amount for which an asset could be exchanged, or liability settled, between knowledgeable and willing parties (Reis \& Stocken, 2007:557). Such a value can be estimated by the market or by auditor modelling (Perry \& Nölke, 2006:562). This represents a major shift in financial reporting, because it removes the direct link between what was paid for an asset and the value being attributed to it.

\section{- $\quad$ Balance sheet approach}

The impact of FVA becomes even more important in the context of the balance sheet approach (or comprehensive income), under which financial performance is judged based on the asset values, as opposed to cash-flow (Van Cauwenberge \& De Beelde, 2007:4; Perry \& Nölke, 2006:563). A concern with this approach is that when combined with FVA, it may lead to increased profit volatility caused by a constant re-measurement of assets.

Even though FVA might reflect the current economic reality more accurately and may have better predictive value, there are subjective assessments in the preparation of FVA statements (Reis \& Stocken, 2007:576). Furthermore, the periodic relativity of values aggravates this valuation predicament (Christensen \& Frimor, 2007: 36-50; Reis \& Stocken, 2007:576). The going-concern postulate underpins the historic cost values in the balance sheet, and abandoning this concept would imply that asset values be reported on a realisable value basis. Seen in this context, cost values may represent more-reliable data for balance sheet purposes. The realisable values under changing conditions may be irrelevant as long as they are not realised. Once the cost object is rendered to the market place, a new exchange of values takes place, which makes it necessary to evaluate the new values, in comparison to the absorbed values. 


\section{A foundational accountancy philosophy}

It is not an exaggeration to consider accountancy as an integral element of the economy as a whole. This needs to be stressed because:

- it places a focus on accountancy's public service role and its responsibility to the community;

- it proves the narrow-mindedness of those who consider accountancy as only a technical or internal function; and

- it points out accountancy's influence on the organisation, the industry and the overall socio-economical environment.

Cluskey et al. (2007:27) found that although accounting theory is alive, the lack of consistency thereof is problematic. Furthermore, accounting theorists seem content to rationalise accounting practice as accounting theory. The real fulfilment of accounting theory would be in its ability to facilitate proper conclusions regarding the business entity's financial performance, regardless of whether functional divisions and procedural differentiations are made in practice. Since the primary aim of accounting is the provision of facts and figures about financial performance, a key objective of GAAP should be to make such information relevant, reliable and comparable.

Therefore, in answering the problem statement, the quintessential meaning of the foregoing may very well serve as a guide on which to formulate a legitimate and underlying accounting philosophy that embraces ethical principles, as follows:

- Accountancy is involved in, and influences, all the economic aspects of the business entity. As such, it has an important social responsibility and it should be practiced in the spirit of accountability and integrity.

- Even though the business entity is an integrated part of society, it remains an economic entity in its own right, operating with the assumption that it will continue to do so indefinitely. Furthermore, the primary purpose and objective of the business entity's existence can be expressed through the products and services it aims to deliver to its intended target market.

- The entity's income and costs, as well as its assets and liabilities, are therefore to be measured according to each item's relative importance to the overall performance of the entity. 
- However, such measurements should not lead to periodic and individual adjustments, based on perceived current fair values, except for the net income and related capital accounts. Doing so may limit the comparability not only between different periods and entities, but also between an entity's internal divisions.

- The net income (profit) amount is the excess of the received value in return for the delivery of the entity's products and services over the values absorbed by these products and services.

Based on this philosophical foundation, there are three essential objectives to which accounting theory should point. Firstly, it is crucial that the primary purpose to be achieved by the recording and collection of the accounting data be clearly understood - being the reporting of the economic events incurred during the organisation's business operations. Secondly, it should facilitate the provision of useful and comparable information concerning the entity's historical economic events as well as the methods used in the preparation thereof. Finally, it should also facilitate the understanding of the business decisions made upon such information, as well as the method(s) used in reaching these decisions.

\section{Concluding comments}

In conclusion, accountancy as a discipline has an important vocational focus. It is, however, grounded on sound scientific concepts, not only within the business sciences, but also in the social sciences. It is imperative that accountants embrace ethical principles in practicing their vocation because of its broad impact on business and society. Even though the GAAP framework aims to define accepted accounting practices, such practices are often open to interpretation and the motives of the accountant.

A topical discussion-point in accountancy related disciplines revolves around the measurement and valuation of items in the accounting reports. Even though we have a great fascination in the reality such accounting information intends to reflect, attempts to reflect the fluctuations in asset value can be seen as changing history and may serve to distort accounting's primary purpose. It can be argued that the performed transactions are the focus of accounting theory, and that relativity and unstableness are not elements of organisational performance. However, relativity and unstableness are crucial factors of organisational planning. Accordingly, the sub-disciplines of managerial accounting and financial management have as their main objective the determination of relative data 
by which the respective values are to be measured. Although greatly involved in, and built upon the accountancy foundation, these are not problems of the basic accounting ideology.

The accounting teachers and professors therefore have a tremendous responsibility in that they play a crucial role in the formative years of accounting students. However, not only should they play a role in teaching accountancy techniques, but how such techniques are to be applied in a responsible manner. Furthermore, it is important that students of accountancy are not merely brainwashed into following rules and accounting conventions, but they should be able to question the discipline, and put it to the test. By teaching future accountants not to merely memorise and apply rules and regulations, accounting professors could truly contribute to the future academic status of the discipline.

\section{List of references}

AICPA see AMERICAN INSTITUTE OF CERTIFIED PUBLIC ACCOUNTANTS

AMERICAN INSTITUTE OF CERTIFIED PUBLIC ACCOUNTANTS. 2003. Code of professional conduct http://ftp.aicpa.org/csc/cpcaf/ethics/ ethics.doc\#l1013 Date of access: 15 Apr. 2008.

ANDREWS, K.R. 2003. Ethics in practice. (In Harvard business review on corporate ethics. Boston: Harvard Business School Press. p. 67-83.)

BLACKBURN, S. 1994. The Oxford Dictionary of Philosophy. Oxford: Oxford University Press.

BUSSE VON COLBE, W.B. 1996. Accounting and the business economics tradition in Germany. The European accounting review, 5(3):413-434.

CAMBRIDGE DICTIONARY OF PHILOSOPHY. 2005. 2nd ed. Cambridge: Cambridge University Press

CANADIAN INSTITUTE OF CHARTERED ACCOUNTANTS. 2005. Comparison of Canadian GAAP and IFRS. http://www.cica.ca/multimedia/Download_ Library/Standards/Accounting/English/e_IFRS.pdf Date of access: 25 Apr. 2008.

CANADIAN INSTITUTE OF CHARTERED ACCOUNTANTS. 2007. The UFE candidates competency map: understanding the professional competencies evaluated by the UFE. http://www.cica.ca/download.cfm? ci_id=40906\&la_id=1\&re_id=0 Date of access: 15 Apr. 2008.

CHRISTENSEN, J. \& FRIMOR, H. 2007. Fair value, accounting aggregation and multiple sources of information. (In Antle, R., Gjestal, F. \& Liang, P.J., ed. Essays in accounting theory in honour of Joel S. Demski. Springer: CICA Science and Business Media. p. 35-51.)

SEe CANADIAN INSTITUTE OF CHARTERED ACCOUNTANTS

CIMA DICTIONARY OF FINANCE AND ACCOUNTING. 2003. London: Bloomsbury. 
CLUSKEY, G.R., EHLEN, C.R. \& RIVERS, R. 2007. Accounting theory: missing in action. Management accounting quarterly, 8(2):24-31.

DAMANT, D. 2006. Discussion of international financial reporting standards (IFRS): pros and cons for investors. Accounting and business research, international policy forum, 29-30.

DEMSKI, J.S. 2007. Is accounting an academic discipline? Accounting horizons, 21(2):153-157.

EPSTEIN, B.J., NACH, R. \& BRAGG, S.M. 2005. GAAP 2006: interpretation and application of generally accepted accounting principles. New Jersey: Wiley.

EVERINGHAM, G.K., KLEYNHANS, J.A.E. \& POSTHUMUS, L.C. 2007. FASB Principles of GAAP. Cape Town: Juta.

see FINANCIAL ACCOUNTING STANDARDS BOARD

FELLINGHAM, J.C. 2007. Is accounting an academic discipline? Accounting horizons, 21(2):159-163.

FELTHAM, G.A. 2007. Joel S. Demski: a leader in accounting scholarship. (In Antle, R., Gjestal, F. \& Liang, P.J., ed. Essays in accounting theory in honour of Joel S. Demski. Springer: Science and Business Media. p. 132.)

FINANCIAL ACCOUNTING STANDARDS BOARD. 2006. Statements of Financial Accounting Standards No. 1XX: The hierarchy of generally accepted accounting principles. http://www.fasb.org/project/gaap_nearfinal.pdf Date of access: 14 May 2008.

GARDNER, J. 1989. Grendel. New York: Vintage.

GELLERMAN, S.W. 2003. Why "good" managers make bad ethical choices. (In Harvard business review on corporate ethics. Boston: Harvard Business School Press. p. 49-66.)

GRAHAM, B. \& MEREDITH, S.B. 1937. The interpretation of financial statements. New York: Harper.

HUSBAND, G.R. 1954. Rationalization in the accounting measurement of ICAA income. The accounting review, 29(1):3-14. ICAEW

see INSTITUTE OF CHARTERED ACCOUNTANTS IN AUSTRALIA

see INSTITUTE OF CHARTERED ACCOUNTANTS OF ENGLAND AND WALES

IFRS

IMA

see INTERNATIONAL FINANCIAL REPORTING STANDARDS

see INSTITUTE OF MANAGEMENT ACCOUNTANTS

INSTITUTE OF CHARTERED ACCOUNTANTS IN AUSTRALIA. 2008. GAAP consulting: complex, international and ever-changing GAAP and GAAS your risks. http://www.gaap.com.au/html/gaap_consulting.html Date of access: 14 May 2008.

INSTITUTE OF CHARTERED ACCOUNTANTS OF ENGLAND AND WALES. 2006. Members handbook: section 3, code of ethics. http://www.icaew. com/index.cfm?route=143703 Date of access: 15 Apr. 2008.

INSTITUTE OF CHARTERED ACCOUNTANTS OF ENGLAND AND WALES. 2008. A-Z of abbreviations: G-L. http://www.icaew.com/index.cfm?route =155642\#g Date of access: 14 May 2008 . 
INSTITUTE OF MANAGEMENT ACCOUNTANTS. 2008. Statement of ethical professional practice. http://www.imanet.org/about ethics_statement.asp Date of access: 15 Apr. 2008.

INTERNATIONAL FINANCIAL REPORTING STANDARDS. 2006. International Financial Reporting Standards (IFRSs ${ }^{\circledR}$ ) London: IASCF Publications Department.

JENSEN, M.C. 2002. Value maximization, stakeholder theory and the corporate objective function. Business ethics quarterly, 12(2):235-256.

LOTRIET, R.A. 2007. Die antitese tussen witboordjiemisdaad en sake-etiek. Koers, 72(3):423-444.

MATTESSICH, R. 2003. Accounting research and researchers of the nineteenth century and the beginning of the twentieth century: an international survey of authors, ideas and publications. Accounting, business and financial history, 125-170.

NASH, L.L. 2003. Ethics without the sermon. (In Harvard business review on corporate ethics. Boston: Harvard Business School Press. p. 19-48.)

O'REGAN, D. 2004. Auditor's dictionary: terms, concepts, processes and regulations. New Jersey: Wiley.

OXFORD ENGLISH DICTIONARY. 2004. Oxford: Oxford University Press.

PERRY, J. \& NÖLKE, A. 2006. The political economy of international accounting standards. Review of international political economy, 13(4):599-586.

REIS, R.F. \& STOCKEN, P.C. 2007. Strategic consequences of historical cost and fair value measurements. Contemporary accounting research, 24(2):557-584.

RIAHI-BELKAOUI, A. 2000. Accounting theory. 4th ed. London: Thomson Learning.

ROSSOUW, G.J. 2002. Business ethics and corporate governance in the second King report: farsighted or futile. Koers, 67(4):405-419.

SAICA

see SOUTH AFRICAN INSTITUTE OF CHARTERED ACCOUNTANTS

SANGSTER, A., STONER, G.N. \& McCARTHY, P. 2008. The market for Luca Pacioli's Summa Arithmetica. Accounting historians journal, 35(1):111134.

SCHROEDER, R.G., CLARK, M.W. \& CATHEY, J.M. 2005. Financial accounting theory and analysis. 8th ed. New Jersey: Wiley.

SHILLAM, P.L. 2008. Focus on the customer. Strategic finance: 23, April.

SOUTH AFRICAN INSTITUTE OF CHARTERED ACCOUNTANTS. 2006. Code of professional conduct. https://www.saica.co.za/ documents/Code_of_ Professional Conduct_2006.pdf Date of access: 15 Apr. 2008.

SOWDEN-SERVICE, C.L. 2006. Gripping GAAP (2007 ed.): your guide to international financial reporting standards. Durban: LexisNexis.

SUNDEM, G.L. 2007. A note on the information perspective and the conceptual framework. (In Antle, R., Gjestal, F. \& Liang, P.J., ed. Essays in accounting theory in honour of Joel S. Demski. Springer: Science and Business Media. p. 285-292.)

VAN CAUWENBERGE, P. \& DE BEELDE, I. 2007. On the IASB comprehensive income project: an analysis of the the case for dual income display. Abacus, 43(1):1-26.

WEBSTER'S DICTIONARY AND THESAURUS. 2006. New Lanark: Geddes \& Grosset. 
WILD, J.J. 2008. Financial accounting: information for decisions. Boston: McGraw-Hill Irwin.

WOLK, H.I., FRANCIS, J.R. \& TEARNEY, M.G. 1992. Accounting theory: a conceptual and institutional approach. 3rd ed. Cincinnati: South-Western Publishing.

ZEFF, S.A. 1986. Big eight firms and the accounting literature: the falloff in advocacy writing. Journal of accounting, auditing and finance, 1(2):131154.

\section{Key concepts:}

accountancy

accounting philosophy

accounting theory

financial reporting

\section{Kernbegrippe:}

finansiële verslagdoening rekeningkundige filosofie rekeningkundige teorie rekenmeesterskap 